\title{
EFFECT OF FEEDING HELIANTHUS TUBEROSUS (JERUSALEM ARTICHOKE) ON RATIONS NUTRITIVE VALUE AND SOME BLOOD PARAMETERS OF OSSIMI RAMS
}

\author{
A.M. Abd El-Mola and G.E. Aboul-Fotouh \\ Animal Production Department, Faculty of Agriculture, Fayoum University, Egypt.
}

(Received 24/7/2018, Accepted 28/8/2018)

\section{SUMMARY}

$\mathrm{T}$ The present study was carried out at farm and laboratory of Animal Production Department- Faculty of Agriculture, Fayoum University, Egypt. Helianthus tuberosus in Ossimi rams rations were evaluated through digestibility, feeding values and some blood parameters. Ossimi rams weighed $45 \pm 5 \mathrm{~kg}$ in average were used to evaluate the rations supplemented by Helianthus tuberosus. The tested rations were $\mathrm{D}_{1}$ (control) composed of $60 \%$ concentrate mixture $(\mathrm{CM})+40 \%$ wheat straw (WS); $\mathrm{D}_{2}, 52.5 \% \mathrm{CM}+$ $7.5 \%$ Helianthus tuberosus (HT) $+40 \%$ (WS); $\mathrm{D}_{3}, 45 \% \mathrm{CM}+15 \% \mathrm{HT}+40 \% \mathrm{WS}$ and $\mathrm{D}_{4}, 30 \% \mathrm{CM}+30 \% \mathrm{HT}$ $+40 \%$ WS. The results revealed that Ossimi rams fed rations of $\mathrm{D}_{2}$ and $\mathrm{D}_{3}$ showed higher significantly values $(\mathrm{P}<0.05)$ of most digestibility coefficients and feeding values compared with control ration. While, insignificant differences were found between $\mathrm{D}_{1}$ and $\mathrm{D}_{4}$ regarding digestibilities and feeding values. The obtained results of some blood parameters showed the same trend of rations digestibilities. Adding Helianthus tuberosus in the rations of $D_{2}$ and $D_{3}(7.5$ and $15 \% H T)$ of Ossimi rams improved nutrients digestibility and feeding values and some blood parameters.

Keywords: Helianthus tuberosus, rams, digestibility coefficients, feeding values and blood parameters.

\section{INTRODUCTION}

Helianthus tuberosus (Jerusalem artichok), a plant of the Asteraceae family that grows in cool to warm climates, also cultivated widely in China for its highly adaptability and multiple tuber usability options, and its tubers can be produced world-wide, including Asia, Europe, and North America. (Slimestad et al., 2010 and Ma, 2011).

Helianthus tuberosus is a valuable fodder, technical and food culture that are becoming more widely used in various industries (Ryazanova et al., 1997). Also, Helianthus tuberosus useful components intended for use as raw materials for foods. Powder Helianthus tuberosus flour contains complex carbohydrate components, represented mainly polysaccharide nature inulin (up to 82\%), proteins (up to $7 \%$ ), fat $(0.3$ $0.7 \%$ ), vitamins (B1, B2, C), pectin (10\%), fiber (7\%), organic acids, macro- and trace elements (Sidorenko and Gorshkov, 2003 and Liflyandskiy, 2006)

Helianthus tuberosus contains many compounds including coumarines, unsaturated fatty acid, polyacetylenic derivatives (Matsuura et al., 1993) and sesquiterpenes (Baba et al., 2005). Therefore, it has various pharmacological activities, such as cholagogue, aphrodisiac, aperient, stomachic, diuretic, and tonic effects. Also, its tuber, a potential source of biomass, is used as food and folk medicine for the treatment of diabetes and rheumatism due to the presence of inulin, which can be converted into fructose. Moreover, it was found that the extracts of the aerial part were also possess antifungal, antimicrobial, and anticancer activities. (Pan et al., 2009) Additionally, Helianthus tuberosus leaf is a natural medicine for the treatment of skin wound, bone fracture and swelling. (Baba et al., 2005). 
Inulin and oligofructose are present naturally in several fruits and vegetables like Jerusalem artichoke, chicory, onion, garlic, banana and others. Helianthus tuberosus is a plant that can serve as an alternative source of carbohydrates. Certain dietary oligosaccharides, such as inulin and oligofructose, are considered as prebiotics and they are possible substitutes for antibiotics (Best, 2000). Other benefits noted with fructooligosaccharides (FOS) or inulin supplementation include increased production of beneficial shortchain fatty acids such as butyrate, Increased absorption of calcium and magnesium, and improved elimination of toxic compounds (Tomomatsu, 1994 and Van den Heuvel et al., 1999).

This study aimed to investigate the effect of partial replacement of concentrate mixture by Helianthus tuberosus in Ossimi rams ration on digestibility coefficient, feeding values and some blood parameters.

\section{MATERIALS AND METHODS}

The experiment was carried out at the Experimental Farm Station, Faculty of Agriculture, Fayoum University, Egypt to study the effect of supplementing Helianthus tuberosus replacement of concentrate mixture in ration of Ossimi rams on feed intake, nutrient digestibility, feeding values and some blood parameters.

\section{Experimental animals}

Twelve Ossimi rams weighted $45 \pm 5 \mathrm{Kg}$ in average were divided into 4 similar groups ( 3 rams each) and fed on the tested ration (Table 1). The tested rations were: the control ration $\left(\mathrm{D}_{1}\right)$ composed of $60 \%$ concentrate mixture (CM) plus $40 \%$ wheat straw (WS). Concentrate mixture were replaced by $12.5,25$ and $50 \%$ of Helianthus tuberosus (HT) on dry matter basis for $\mathrm{D}_{2}, \mathrm{D}_{3}$ and $\mathrm{D}_{4}$, respectively. These replacements formed 7.5, 15 and $30 \%$ of the total rations dry matter for $D_{2}, D_{3}$ and $D_{4}$, respectively. Thus, four tested rations were performed.

\section{Digestibility trial}

Digestibility trial was carried out to evaluate the nutrients digestibility and nutritive value of the tested rations. The animals were individually placed in metabolic cage for 15 day as a preliminary period followed by 7 days as a collection period. The ration was offered daily and refused if found were recorded every day. Total feces were daily collected and weighted. Feces sample (10\%) was taken, sprayed with $10 \% \mathrm{H}_{2} \mathrm{SO}_{4}$ and dried at $60^{\circ} \mathrm{c}$ for 24 hours, then it was ground and kept for chemical analysis. Samples of offered feeds were composite dried separately, finally ground and kept for chemical analysis according to the methods of the A.O.A.C. (1995). Gross energy (GE) and digestible energy (DE) of feeds were calculated after Nehring and Haenlien (1973).

\section{Blood analysis}

Blood samples were taken at the end of the digestion trail before the morning feeding from the jugular vein. The samples were directly collected into vacuum tube and centrifuged at $3000 \mathrm{rpm}$ for $5 \mathrm{~min}$. serum was separated into polypropylene tube and stored at $-18{ }^{\circ} \mathrm{C}$ until analysis for total protein and albumin according to Weichselbaum, (1946) and Doumas et al. (1971), respectively. Globulin value was calculated by the differences between total protein and corresponding value of albumin. The total lipids was determined following method of Boutwell (1972), while cholesterol following Allain et al. (1974).

\section{Statistical analysis}

Data of the digestibility trial and some blood parameters were analyzed using general linear model procedure by computer program of SPSS (1997) and the differences between means were tested using Duncans new multiple test (Duncan, 1955). The statistical model was as follows: $\mathrm{Yij}=\mathrm{m}+\mathrm{Ai}+$ eij Where Yij is dependent variable; $\mathrm{m}=$ overall mean; $\mathrm{Ai}=$ is the effect of treatment and $\mathrm{eij}=\mathrm{is}$ the experimental error. 
Table (1): Formula of the tested rations used in digestibility trial, on dry matter basis.

\begin{tabular}{lcccc}
\hline \multirow{2}{*}{ Item } & \multicolumn{3}{c}{ Tested rations } \\
\cline { 2 - 5 } & $\mathrm{D}_{1}$ (control) & $\mathrm{D}_{2}$ & $\mathrm{D}_{3}$ & $\mathrm{D}_{4}$ \\
\hline Concentrate mixture*, \% & 60 & 52.5 & 45 & 30 \\
Wheat straw, \% & 40 & 40 & 40 & 40 \\
Helianthus tuberosus, $\%$ & -- & 7.5 & 15 & 30
\end{tabular}

* Concentrate mixture consisted of $22 \%$ soybean cake, $50 \%$ yellow corn, $10 \%$ rice bran, $10 \%$ wheat straw, $3.5 \%$ molasses, $3 \%$ lime stone, $1 \%$ common salt and $0.5 \%$ minerals mixture.

\section{RESULTS AND DISCUSSION}

\section{Chemical composition of the tested ration}

Chemical composition of concentrate mixture, wheat straw, Helianthus tuberosus and tested rations are presented in Table (2). Helianthus tuberosus was higher of nitrogen free extract $(69.65 \%)$ compared with concentrate mixture which was $48.61 \%$. Also, crude protein of HT was $9.8 \%$ which was nearly similar to yellow corn. Crude fiber of HT was very lower (4.14\%) than concentrate mixture which $15.32 \%$ was. Ash of HT had the same trend of crude fiber but gross energy (GE) of HT was similar to concentrate mixture and wheat straw. Also, chemical composition of Helianthus tuberosus was nearly similar to yellow corn. Thus, has been replaced to concentrate mixture.

Table (2): Chemical analyses of ingredients and tested rations (on DM basis).

\begin{tabular}{lcccccccc}
\hline & & \multicolumn{7}{c}{ \% on DM basis } \\
\cline { 3 - 9 } Item & DM\% & OM\% & CP\% & EE\% & CF\% & NFE\% & $\begin{array}{c}\text { Ash\% } \\
\text { GE Mcal/ } \\
\text { kgDM }\end{array}$ \\
\hline Concentrate mixture & 91.44 & 84.09 & 16.54 & 3.62 & 15.32 & 48.61 & 7.35 & 3.84 \\
Helianthus tuberosus & 92.07 & 85.78 & 9.80 & 2.19 & 4.14 & 69.65 & 6.29 & 3.83 \\
Wheat straw & 91.54 & 79.81 & 3.89 & 1.85 & 33.42 & 40.65 & 11.73 & 3.81 \\
& & & & & & & & \\
$\mathrm{D}_{1}$ (control) & 91.48 & 82.38 & 11.48 & 2.91 & 22.56 & 45.43 & 9.10 & 3.84 \\
$\mathrm{D}_{2}$ & 91.53 & 82.50 & 10.97 & 2.80 & 21.72 & 47.00 & 9.02 & 3.83 \\
$\mathrm{D}_{3}$ & 91.57 & 82.63 & 10.47 & 2.70 & 20.88 & 48.58 & 8.94 & 3.81 \\
$\mathrm{D}_{4}$ & 91.67 & 82.89 & 9.458 & 2.483 & 19.21 & 51.738 & 8.78 & 3.78 \\
\hline
\end{tabular}

${ }^{*} G E=$ tested diet three ( $30 \%$ concentrate mixture $+40 \%$ wheat straw +30 Helianthus tuberous)

\section{Digestibility and nutritive values}

The results in Table (3) showed that digestion coefficient of dry matter (DM\%) was $58.83 \%$ in control diet $\left(D_{1}\right)$ and was $63.04 \%, 62.08 \%$ and $59.31 \%$ of $D_{2}, D_{3}$ and $D_{4}$, respectively with significant differences $(\mathrm{P}<0.05)$. Organic matter $(\mathrm{OM} \%)$ digestibility almost followed the same trend of DM digestibility. Digestion coefficient of crude protein (CP \%) ranged between $58.52 \%$ and $73.59 \%$ being significantly $(\mathrm{P}<0.05)$ higher in $\mathrm{D}_{2}$ than those of $\mathrm{D}_{4}$ and control one. Digestion coefficient of ether extract $(\mathrm{EE} \%)$ was nearly similar to the trend of CP digestibility. Generally, ration D2 (7.5\% Helianthus tuberosus) showed the highest digestibilities of all nutrients especially when compared with $\mathrm{D}_{1}$ (control ration) or $\mathrm{D}_{4}$. 
Table (3): Digestion coefficients and feeding values of the tested rations (on DM basis) fed to Ossimi rams.

\begin{tabular}{|c|c|c|c|c|c|}
\hline \multirow[b]{2}{*}{ Item } & \multicolumn{4}{|c|}{ Tested Rations } & \multirow[b]{2}{*}{$\pm \mathrm{SE}$} \\
\hline & $\mathrm{D}_{1}$ (control) & $\mathrm{D}_{2}$ & $\mathrm{D}_{3}$ & $\mathrm{D}_{4}$ & \\
\hline \multicolumn{6}{|c|}{ Digestion coefficients \% } \\
\hline DM & $58.83^{\mathrm{c}}$ & $63.04^{\mathrm{a}}$ & $62.08^{\mathrm{ab}}$ & $59.31^{\text {bc }}$ & \pm 0.651 \\
\hline $\mathrm{OM}$ & $62.99^{c}$ & $67.81^{\mathrm{a}}$ & $65.87^{\mathrm{b}}$ & $63.16^{\mathrm{c}}$ & \pm 0.685 \\
\hline $\mathrm{CP}$ & $58.52^{\mathrm{b}}$ & $73.59^{\mathrm{a}}$ & $69.58^{\mathrm{ab}}$ & $59.53^{\mathrm{b}}$ & \pm 2.509 \\
\hline $\mathrm{EE}$ & $75.44^{\mathrm{b}}$ & $79.85^{\mathrm{a}}$ & $77.91^{\mathrm{ab}}$ & $76.17^{\mathrm{ab}}$ & \pm 0.687 \\
\hline $\mathrm{CF}$ & $52.68^{\mathrm{c}}$ & $59.00^{\mathrm{a}}$ & $56.45^{\mathrm{b}}$ & $51.51^{\mathrm{c}}$ & \pm 0.942 \\
\hline NFE & $68.99^{\mathrm{b}}$ & $73.93^{\mathrm{a}}$ & $72.67^{\mathrm{a}}$ & $70.38^{b}$ & \pm 0.643 \\
\hline \multicolumn{6}{|l|}{ Feeding values } \\
\hline TDN , \% & $54.88^{\mathrm{b}}$ & $60.67^{\mathrm{a}}$ & $59.10^{\mathrm{a}}$ & $56.17^{\mathrm{b}}$ & \pm 0.312 \\
\hline DCP, $\%$ & $6.72^{\mathrm{bc}}$ & $8.07^{\mathrm{a}}$ & $7.28^{\mathrm{ab}}$ & $5.63^{\mathrm{c}}$ & \pm 0.312 \\
\hline DE (Mcal/KgDM) & $237.59^{\mathrm{b}}$ & $263.61^{\mathrm{a}}$ & $248.73^{b}$ & $261.82^{\mathrm{a}}$ & \pm 3.499 \\
\hline $\mathrm{GE}(\mathrm{Mcal} / \mathrm{KgDM})$ & 384.43 & 382.80 & 381.27 & 378.05 & \pm 0.709 \\
\hline
\end{tabular}

Average in the same row with different superscripts are different $(P \leq 0.05)$ for $a, b$ and $c$.

These results were in agreement with those obtained by Swanson et al. (2002); Strickling et al. (2000) and Flickinger et al. (2003). Samal et al. (2017) showed that supplementation of Jerusalem artichoke (JA) to diets improved digestibility coefficient of CP, EE and CF when addition JA tuber powder (JA 0,2,4 and 6\% pulverized) in rats and better absorption of calcium and phosphorus. Pradhan et al. (2015) observed a reduction in protein digestibility upon dietary supplementation with $2 \%$ of Helianthus tuberosus in the diet. Increased CF digestibility in Helianthus tuberosus -fed rams is in agreement with the findings of Zentek et al. (2002) and Samal et al. (2012) also recorded increased CF digestibility when Helianthus tuberosus was included in the diet.

Pawar (2007) and Kore et al. (2012) who used MOS as a prebiotic. The digestibility of CF was improved by dietary supplementation with Helianthus tuberosus. The increase in Lactobacillus spp. and Bifidobacterium spp. populations by Helianthus tuberosus addition represents a clear improvement in the status of eubiosis. This may be the result of selective fermentation of inulin and fructooligosaccharides (FOS) by these beneficial bacteria in the hindgut.

Inulin-type fructans are either synthesized from sucrose or prepared commercially from inulin-rich plants such as chicory (Cichorium intybusL.) root and Helianthus tuberosus tuber. The yield potential, both for biomass and sugars, is higher in Helianthus tuberosus than chicory. The Helianthus tuberosus plant shows good frost and drought tolerance, is resistant to diseases and can achieve a high yield of biomass (Slimestad et al., 2010). The inulin content in Helianthus tuberosus tuber ranges from 7 to $30 \%$ of fresh weight (Kays and Nottingham, 2007) or from 60 to $85.5 \%$ of dry weight (Aduldecha et al., 2016). Tubers of Helianthus tuberosus have high metabolizable energy content of $15 \mathrm{MJ} \cdot \mathrm{kg}-1$ dry matter (Kleessen et al., 2007)

\section{Some blood Parameters}

The results of some blood constituents are shown in Table (4). The obtained values were in normal range. Concentration of total protein and albumin were significantly $(\mathrm{P}<0.05)$ higher in $\mathrm{D}_{2}$ which consisted $7.5 \%$ Helianthus tuberosus than $\mathrm{D}_{1}$ and $\mathrm{D}_{3}$. No significant differences were found between $\mathrm{D}_{2}, \mathrm{D}_{3}$ and $\mathrm{D}_{4}$ regarding globulin concentration. Meanwhile, $\mathrm{D}_{2}$ and $\mathrm{D}_{3}$ differed significantly $(\mathrm{P}<0.05)$ compared to $\mathrm{D}_{1}$ (control ration). Concentration of cholesterol and creatinine were increased $(\mathrm{P}<0.05)$ significantly in $\mathrm{D}_{1}$ (control diet) than the other diets. AST and ALT were not significantly different $(\mathrm{P}<0.05)$ among treatment. These results indicated that animals were generally in a good nutritional status and livers were in normal physiological conditions. Tiengtam et al. (2017) found that supplementation with inulin at $5 \mathrm{~g} / \mathrm{kg}$ or Jerusalem artichoke. While Nile tilapia diet it did not affect any significant changes in several blood metabolites, including glucose, cholesterol, triglyceride or albumin. A previous study in juvenile tilapia revealed that dietary inulin or Jerusalem artichoke had no effect on cholesterol or triglyceride; however, 
both increased glucose, plasma protein and albumin (Tiengtam et al., 2015). Such differences may reflect the effect of animal used or the level of Helianthus tuberosus in the ration.

Table (4): Some blood parameters of tested diets (on DM basis) fed to Ossimi rams.

\begin{tabular}{llllll}
\hline Item & \multicolumn{4}{c}{ Tested rations } & \multicolumn{2}{c}{ \pm} \\
\cline { 2 - 6 } & $\mathrm{D}_{1}$ (control) & $\mathrm{D}_{2}$ & $\mathrm{D}_{3}$ & $\mathrm{D}_{4}$ & \\
\hline Total protein(g/dl) & $5.72^{\mathrm{b}}$ & $6.91^{\mathrm{a}}$ & $5.57^{\mathrm{b}}$ & $6.48^{\mathrm{ab}}$ & 0.201 \\
Albumin(g/dl) & $2.93^{\mathrm{c}}$ & $3.49^{\mathrm{a}}$ & $3.17^{\mathrm{b}}$ & $3.20^{\mathrm{b}}$ & 0.063 \\
Globulin(g/dl) & $3.19^{\mathrm{b}}$ & $3.55^{\mathrm{a}}$ & $3.60^{\mathrm{a}}$ & $3.27^{\mathrm{ab}}$ & 0.067 \\
Cholesterol(mg/dl) & $98.40^{\mathrm{a}}$ & $94.57^{\mathrm{bc}}$ & $93.48^{\mathrm{c}}$ & $96.91^{\mathrm{ab}}$ & 0.683 \\
Triglycerides(mg/dl) & $51.07^{\mathrm{a}}$ & $50.14^{\mathrm{bc}}$ & $49.83^{\mathrm{c}}$ & $50.71^{\mathrm{ab}}$ & 0.172 \\
Creatinine $(\mathrm{mg} / \mathrm{dl})$ & $1.20^{\mathrm{a}}$ & $1.13^{\mathrm{ab}}$ & $1.04^{\mathrm{b}}$ & $1.11^{\mathrm{ab}}$ & 0.023 \\
ALT $(\mathrm{u} / \mathrm{ml})$ & 28 & 27 & 27 & 28 & 0.328 \\
AST $(\mathrm{u} / \mathrm{ml})$ & 43 & 40 & 41 & 42 & 0.835 \\
\hline
\end{tabular}

Average in the same row with different superscripts are different $(P \leq 0.05)$ for $a, b$ and $c$.

The Helianthus tuberosus addition into diets significantly $(\mathrm{P} \leq 0.05)$ increased total short-chain fatty acids concentrations as the level of Jerusalem artichoke in the diet increased. Also, lactic acid content was increased and ammonia concentration was reduced in feces due to Helianthus tuberosus supplementation (Samal et al., 2017). These findings may suggest the obtained results of total protein and triglycerides.

\section{CONCLUSION}

Supplementing Helianthus tuberosus to the ration of Ossimi rams as replacement with $7.5 \%$ and $15 \%$ improvement nutrient digestibility, feeding values and some blood parameters. Also, more researches were needed to examine different levels of Helianthus tuberosus in the diets with different animal types.

\section{REFERENCES}

A.O.A.C. (1995). Association of Official Analytical Chemists. Official Methods of Analysis. $16^{\text {th }}$ ed. Washington, D.C., USA.

Aduldecha, C.; W. Kaewpradit; N. Vorasoot; D. Puangbut; S. Jogloy and A. Patanothai (2016). Effects of water regimes on inulin content and inulin yield of Jerusalem artichoke genotypes with different levels of drought tolerance. Turk. J. Agric. For. 40, 335-343, https://doi.org/10.3906/tar-1506-39

Allain, C. C.; L. S. Poon; C. S. Chan; W. Richmond and P. C. Fu (1974). Enzymatic determination of total serum cholesterol. Clin. Chem., 20:470-475.

Baba, H.; Y. Yaoita and M. Kikuchi (2005). Sesquiterpenoids from the leaves of Helianthus tuberosus L. J Tohoku Pharm Univ. 52:21-5.

Best, P. (2000): Starter pig feeds: Oligosaccharides. Do these feed sugars assist the right bacteria? Feed Int., $2,24$.

Boutwell, J.H.M. (1972). USD.H.E.W. pamphlet.

Doumas, B.; W. Wabson and H. Biggs (1971). Albumin standards and measurement of serum with bromocresol green. Clinical Chemistry 31:87.

Duncan, D. B. (1955). Multiple range and multiple F test. Biometrics. 11:1-42. 
Flickinger, E. A.; E. M. W. C. Schreijen; A. R. Patil; H. S. Hussein; C. M. Grieshop; N. R. Merchen and Jr. G. C. Fahey (2003). Nutrient digestibilities, microbial populations and protein catabolites as affected by fructan supplementation of dog diets. J. of Anim. Sci., 81: 2008-18.

Kays, S.J. and S.F. Nottingham (2007). Chemical composition and inulin chemistry. In: Biology and Chemistry of Jerusalem Artichoke: Helianthus tuberosusL. CRC Press, Boca Raton, FL (USA), pp. 5396, https://doi.org/10.1201/9781420044966.ch5

Kleessen, B.; S. Schwarz; A. Boehm; H. Fuhrmann; A. Richter; T. Henleand and M. Krueger (2007). Jerusalem artichoke and chicory inulin in bakery products affect faecal microbiota of healthy volunteers. Br. J. Nutr. 98, 540-549, https://doi.org/10.1017/ S0007114507730751.

Kore, K.B.; A.K. Pattanaik; A. Dasand and K. Sharma (2012). Evaluation of mannanoligosaccharide as prebiotic functional food for dogs: effect on nutrient digestibility, hind gut health and plasma metabolic profile. Indian J. Anim. Sci. 82, 81-86.

Liflyandskiy, V.G. (2006).Vitamins and minerals. From A to Ya. -Sankt Petersburg: Publishing House "Neva".

Ma, X.Y; L.H. Zhang; H.B. Shao; G. Xu; F. Zhang and F.T. Ni. (2011). Jerusalem artichoke (Helianthus tuberosusL.), a medicinal salt-resistant plant has high adaptability and multiple-use values. J. Med. Plant Res. 5(8):1275-82.

Matsuura, H.; T. Yoshihara and A. Ichihara (1993). Four New Polyacetylenic Glucosides, Methyl $\beta$-DGlucopyranosyl Helianthenate C-F, from Jerusalem artichoke (Helianthus tuberosus L.) Biosci Biotechnol Biochem; 57(9):1492-8.

Nehring, K. and G.F.W. Haenlien (1973). Feed evaluation and ration calculation based on net energy. J. Anim. Sci., 36: 949.

Pan, L.; M. R. Sinden; A.H. Kennedy; H. Chai; L.E. Watson and T. L. Graham (2009). Bioactive constituents of Helianthus tuberosus L. (Jerusalem artichoke). Phytochem Lett; 2(1):15-8.

Pawar, M.M. (2007). Optimization of homemade diet through supplementation and use of prebiotics in pet dog .M.V.Sc. Thesis Submitted to IVRI, Deemed University, Izatnagar (India).

Pradhan, S.K.;A. Das; S.S. Kullu; M. Saini; A.K. Pattanaik; N. Dutta and A.K. Sharma (2015). Effect of feeding Jerusalem artichoke (Helianthus tuberosus) root as prebiotic on nutrient utilization, fecal characteristics and serum metabolite profile of captive Indian leopard (Pantherapardusfusca) fed a meaton-bone diet. Zoo Biol. 34, 153-162, https://doi.org/10.1002/zoo.21187.

Ryazanova, T.V.; L.A. Dorofeeva and A.V. Bogdanova (1997). Chemical composition of the vegetative part of Jerusalem artichoke and its use. Forest magazine.

Samal, L.; V.B. Chaturvedi and A.K. Pattanaik (2017). Effects of dietary supplementation with Jerusalem artichoke (Helianthus tuberosus L.) tubers on growth performance, nutrient digestibility, activity and composition of large intestinal microbiota in rats. J. of Anim. and Feed Sci. 26, 2017, 5058,https://doi.org/10.22358/jafs/68779/2017.

Samal, L.; V.B. Chaturvedi; S. Baliyan; M. Saxena and A.K. Pattanaik (2012). Jerusalem artichoke as a potential prebiotic: influence on nutrient utilization, hindgut fermentation and immune response of Labrador dogs. Anim. Nutr. Feed Technol. 12, 343-352

Sidorenko, S.M. and Gorshkov (2003). A method for producing dried tubers of Jerusalem artichoke M.F.

Slimestad, R.; R. Seljasen; K. Meijer and S.L. Skar (2010). Norwegian-grown Jerusalem artichoke (Helianthus tuberosus L.): Morphology and content of sugars and fructo-oligosaccharides in stems and tubers. J. Sci. Food Agric., 90 (6):956-64.

SPSS (1997). Statistical Package for Social Science release 8.0 copyright (c), SPSS INC., Chicago, USA.

Strickling, J. A.; D. L. Harmon; K. A. Dawson and K. L. Gross (2000). Evaluation of oligosaccharide addition to dog diets: Influences on nutrient digestion and microbial population. Anim. Feed Sci. and Tech., 86: 205-19. 
Swanson, K. S.; C. M. Grieshop; E. A. Flickinger; L. L. Bauer; H. P. Healy; K. A. Dawson; N. R. Merchen and G. C. Jr. Fahey (2002). Supplemental fructooligosaccharides and mannanoligosacchrides influence immune function, ileal and total tract nutrient digestibilities, microbial population and concentrations of protein catabolites in the large bowel of dogs. J. of Nutr. 132: 980-89.

Tiengtam, N.; P. Paengkoum; S. Sirivoharn; K. Phonsiri and S. Boonanuntanasarn (2017). The effects of dietary inulin and Jerusalem artichoke (Helianthus tuberosus) tuber on the growth performance,haematological, blood chemical and immune parameters of Nile tilapia (Oreochromis niloticus) fingerlings. Aquaculture Research, 00:1-9.

Tiengtam, N.; S. Khempaka; P. Paengkoum and S. Boonanuntanasarn (2015). Effects of inulin and Jerusalem artichoke (Helianthus tuberosus) as prebiotic ingredients in the diet of juvenile Nile tilapia (Oreochromis niloticus). Anim. Feed Sci. and Tech., 207, 120- 129.

Tomomatsu, H. (1994): Health effects of oligosaccharides. A review. Food Technol., 61, 5. University of Maryland Medical Center. Traditional Chinese Medicine. [Updated 24 August 2009; 19 April 2014]; Available from: www.umm.edu/altmed/articles/traditional-chinese- 000363.htm.

Van den Heuvel, E.G; T. Muys; W. van Dokkum and G. Schaafsma (1999). Oligofructose stimulates calcium absorption in adolescents. Am. J. Clin. Nutr., 69, 544-548.

Weichselbaum, T. E. (1946). Quantitative colorimetric determination of total protein in serum. American J. Clinical Pathology. 7:40-45.

Zentek, J.; B. Marquart and T. Pietrzak (2002). Intestinal effects of mannan-oligosaccharides, trans galactooligosaccharides, lactose and lactulose in dogs. J. Nutr. 132, 1682-1684.

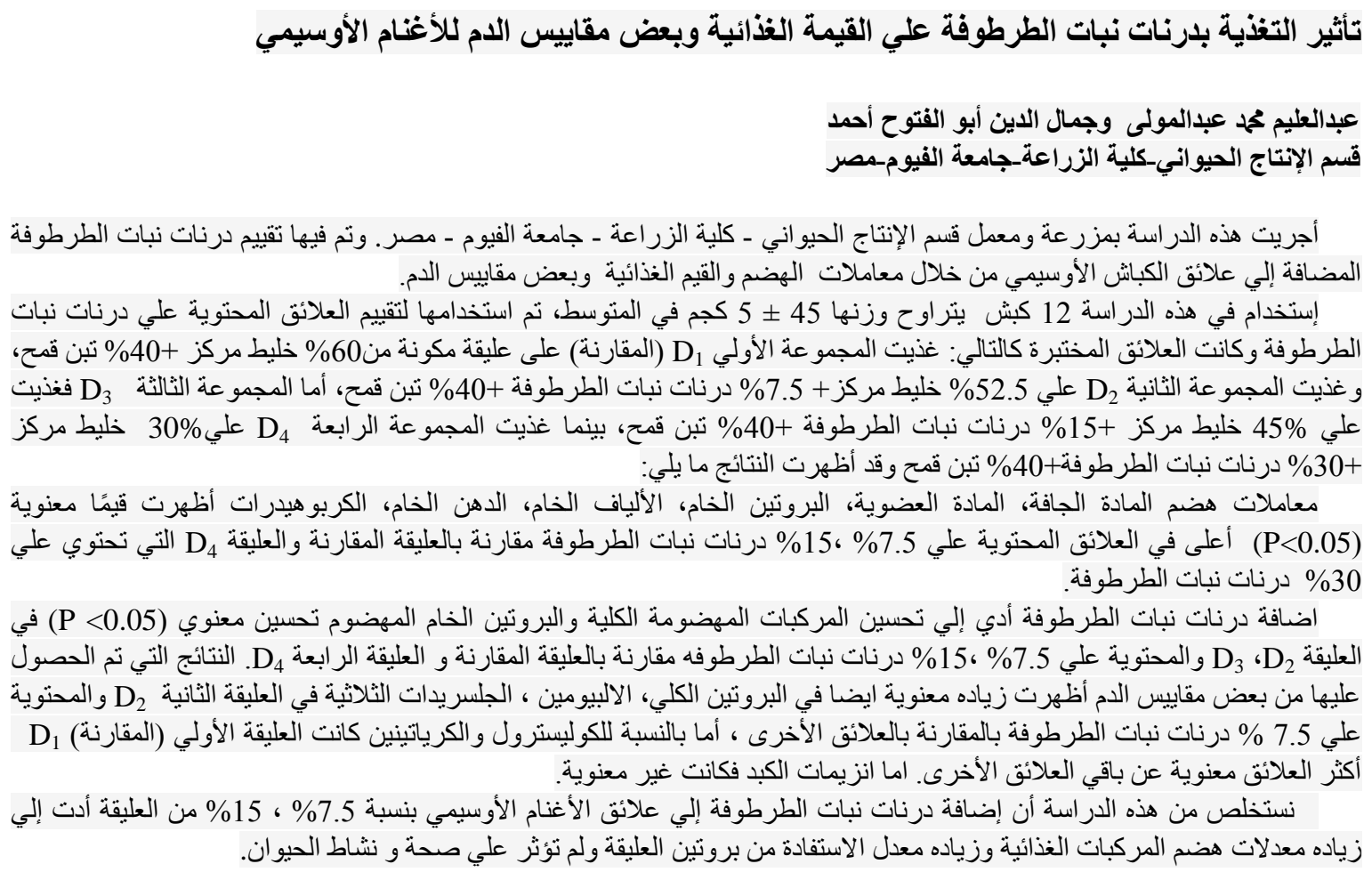

